\title{
ВЗАИМОСВЯЗЬ ФАРМАКОКИНЕТИКИ И ФАРМАКОДИНАМИКИ С ФАРМАЦЕВТИЧЕСКОЙ РАЗРАБОТКОЙ
}

\author{
М.В. Карлина, М.Н. Макарова, В.Г. Макаров \\ Группа фармакокинетики, ЗАО «Санкт-Петербургский институт фармации», \\ 188633, Россия, Ленинградская область, Всеволожский район, \\ г.п. Кузьмоловский, ул. Заводская, д.3 корп. 245.
}

DOI: 10.19163/MedChemRussia2021-2021-204

E-mail:karlina.mv@doclinika.ru

Фармацевтическая разработка инновационного высокоэффективного и конку-рентоспособного лекарственного препарата является долгим и дорогостоящим процессом, результат которого достаточно сложно спрогнозировать заранее. Для ускорения выхода нового препарата на рынок и снижения материальных затрат разработчика необходимо использовать риск-ориентированный подход к фармацевтической разработке (определение целевого профиля лекарственного средства, установление критических показателей качества, оценка рисков, установление пространства проектных параметров, разработка стратегии контроля), что позволит эффективно управлять жизненным циклом препарата [1].

Процесс создания препарата неразрывно связан с проведением доклинических исследований (фармакокинетики, фармакодинамики и токсичности), объем которых определяется, как правило, уже после выбора состава лекарственного средства. Согласно нормативным документам отчет по доклиническим испытаниям составляет значительную часть регистрационного досье с целью государственной регистрации лекарственного препарата [2]. Однако на этапе доклинических исследований может быть установлено, что разработанный препарат малоэффективен, обладает низкой биодоступностью, не обладает требуемыми фармакокинетическими характеристиками и т.д. В этом случае разработчик будет вынужден снова вернуться к работе над выбором лекарственной формы и состава препарата.

Для повышения вероятности успешности фармацевтической разработки необходимо проведение пилотных экспериментов по изучению фармакокинетики и/или фармакодинамики на этапе выбора лекарственной формы и ее состава. Проведение подобных экспериментов позволяет разработать лекарственный препарат с оптимальным фармакокинетическим профилем, снизить количество доклинических исследований и обеспечить успешную трансляционность данных в клиническую практику.

\section{Литература}

[1] А. Феофилова, А. Фотеева, Н. Ростова, Разработка и регистрация лекарственных средств. 2020, T.9, №4, 171-179.

[2] Решение Совета ЕЭК №78 «О правилах регистрации и экспертизы лекарственных средств для медицинского применения» от 03.11.2016 г

$$
-204-
$$

